日臨外医会誌 $56(1), 6-10,1995$

原著

僧帽弁狭窄症直視下交連切開術後の抗凝固療法の

有用性に関する研究

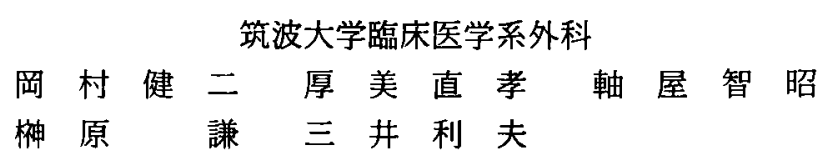

OMC 後の抗凝固療法の有用性に関して, 抗凝固療法を行わなかった群36例（I 群）, 行った群28例（II群）について血栓塞拴症 event free rate, 遠隔期死亡原因, 累積生存 率の分析から検討した，同時に抗凝固療法の有無，心房細動，左房内血栓，術前血栓塞 栓症の有無, NYHA 臨床度と血栓塞栓症の発生との相関について, 多変量解析からその 順位つけを行った，抗凝固療法の内容は抗血小板剂服用例 $68 \%$, varfarin 服用例 $32 \%$ て あった．血栓塞栓症の合併率はＩ，II群でそれぞれ $2.7 \% / \mathrm{py}, 0.4 \% / \mathrm{py}$ と I 群に有意に 高く event free rate は術後11年目でII群の $90 \pm 9 \%$ に比べ I 群では77 $10 \%$ と有意に低 かった．累積生存率は 11 年目でII群の $95 \pm 5 \%$ に比へ】群では $87 \pm 6 \%$ と有意に低值を示 した. 血栓塞栓症の危険因子のうち抗凝固療法の有無がその発生と最も高い相関を示し た。 OMC 後の抗疑固療法, ことに抗血小板剤は血栓塞拴症の予防と累積生存率の改善に 有用であった。

索引用語：僧帽弁狭窄症, 直視下交連切開術, 血栓塞栓症, 抗凝固療法, 抗血小板療法

\section{緒言}

人工弁置換術の最も重篤な合併症の一つとして, 血 栓塞栓症は重要視され, これまで数多くの予防的治療 としての抗凝固療法が研究されてきたが, 僧帽弁狭窄 症の交連切開術後においては抗凝固療法が基本的に不 要であることが利点と考えられ", 全く行わない"か左 房内血栓があった場合 ${ }^{21}$, 心房細動に移行した場合”に 一時的に行うなど系統的に治療が行われていない現況 にある。

その発生頻度は人工弁に上る僧帽弁置換術の $1.6 \sim 2.5 \% /$ 患者・年 $(\mathrm{py})^{3)-5)}$ に比べ交連切開術でも $1.2 \sim 1.8 \% / \mathrm{py}^{3 / 6)}$ と若干少ない傾向にあるが, 無視さ れてよい頻度ではない．前者が時に血栓弁という致死 的に重篤な合併症を引き起こすことがあることが人工 弁置換術後に抗凝固療法の研究が集中する主たる理由 と思われる.しかし，血栓塞栓症がひとたび合併する と,例えば最も多い脳血栓症では半身不随に陥ったり, 時には急死することもあり，その予防的治療に関する 研究は極めて重要である.

1994年 6 月 2 日受付 1994年10月25日採用
本研究ては直視下僧帽弁交連切開術 (OMC) 術後に おける抗凝固療法の血栓塞栓症予防効果について模討 した.

\section{对象と方法}

1977年 5 月から1990年12月までに当病院において僧 帽弁狭窄症に対して OMCを受けた64例を対象とし た. 年齢は 25 歳から61歳, 平均 $45 \pm 8$ 歳. 性比は男性 20 例, 女性44例。 NYHE 臨床度はII度29例, III度33例, IV 度 2 例。このうち抗凝固療法を行わなかった 36 例を I 群, 何らかの抗凝固療法を行った28例をII群として, 血栓症 event free rate, 遠隔期死亡原因, 累積生存率 を比較検討した.

血栓塞栓症の危険因子としては，これまで抗凝固療 法の有無以外に NYHA 臨床度, 心房細動の有無, 左房 内血栓の有無, 術前血栓塞栓症の既往の有無 ${ }^{(1)}$ )など が指摘されている.そこで，これらの危険因子と血栓 塞栓症の発生との相関の順位づけを多変量解析から 行った.さらに抗凝固療法の有無により分類した I, II 群間の各危険因子の割合を比較検討した。

II 群のうち，抗血小板剂を抗凝固療法として用いた 19例の第一選択は aspirin であるが，気管支喘息など 
服用による合併症があった場合には dipyridamoleゃ ticulopidine に変更した。 aspirin の服用量は $330 \mathrm{mg}$ を 基本としたが，出血を訴えた 1 例については $81 \mathrm{mg}$ に変更した. dipyridamole の服用量は300mg, ticulopidine は $300 \mathrm{mg}$ を基本とした。抗血小板棛服用 中の合併症（胃腸障害など）に対しては，他剤への変 更と抗謴湯郕（主として防御因子増強郕）を併用する などして対応し，抗血小板剤としての服用中の dropoutはなかった．過去に明らかな血栓塞拴症の既往 (hemiplegia など)があり, 術中に左房内血栓が認めら れたり，僧帽弁の形状などから血栓塞栓症の合併する 可能性が高いと判断された 9 例については warfarin による抗㠜固療法を行った. warfarin 服用例について は prothrombin time で50\%前後をコントロール目標 とした.

遠隔追跡期間は1993年12月末まてとし, 病状の調査 は外来カルテ，転院例では電話による問い合わせ（病 院もしくは自宅）により行った，追跡期間はＩ群で平 均9.5 \pm 3.8 年, 最長15.6年, II 群で平均8.4 43.8 年, 最長16.1年, 遠隔追跡率はそれぞれ97.2\%,100\%,累 積追跡期間はそれぞれ334.0py, 234.7pyであった(表 1). 累積生存率, event free rate は Anderson の方 法12)により計算した。統計的処理は両側 $\mathrm{t}$ 検定または 両㑡 $\mathrm{z}$ 検定を用い, $\mathrm{p}<0.05$ 以下を有意とした.

$$
\text { 結 果 }
$$

血栓塞栓症の塞栓部位，合併時期，予後を表 2 に示 す. 合併率は I, II群でそれぞれ $2.7 \% / \mathrm{py}, 0.4 \% / \mathrm{py}$ とI群に有意に高かった $(\mathrm{p}<0.05)$. 血拴塞栓症 event free rate は術後11年目で, II群の $90 \pm 9 \%$ に比へ, I 群 では77士10\%と有意（p<0.001）に低值を示した（図
Table 1 The patients' preoperative clinical features

\begin{tabular}{l|c|c|c}
\hline & Group I & Group II & P value \\
\hline No. of patients & 36 & 28 & \\
\hline Age (Years) & & & \\
mean \pm SD & $46 \pm 8$ & $45 \pm 9$ & NS \\
range & $27-60$ & $25-61$ & \\
\hline Sex (M/F) & $11 / 25$ & $8 / 20$ & NS \\
\hline Follow-up period & & & \\
(Years) & & & \\
mean \pm SD & $9.5 \pm 3.8$ & $8.4 \pm 3.7$ & NS \\
range & $1.6-15.6$ & $3.1-16.1$ & \\
cumulative & 334.0 & 234.7 & \\
\hline Lost to follow-up & $1(2.8 \%)$ & $0(0 \%)$ & \\
\hline
\end{tabular}

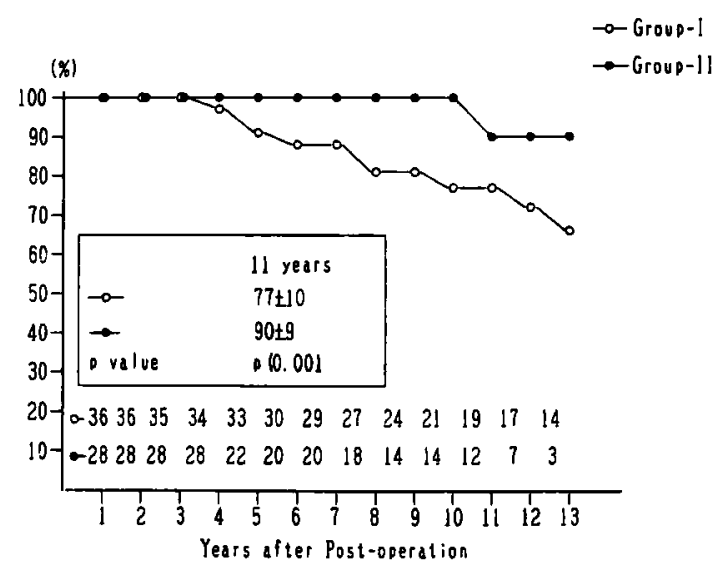

Fig. 1 Thromboembolism-free rates

1).

遠隔期死亡原因を表 3 に示す.I 群では 6 例 $(1.8 \%$ I

Table 2 Position of thromboembolism, duration after operation and prognosis in patients with thromboembolism

\begin{tabular}{c|c|c|c|l|c|c}
\hline $\begin{array}{c}\text { Patient's } \\
\text { No. }\end{array}$ & Sex & Years & Group & $\begin{array}{c}\text { Position of } \\
\text { thromboembolism }\end{array}$ & $\begin{array}{c}\text { Duration after } \\
\text { operation (Years) }\end{array}$ & Prognosis \\
\hline I & F & 47 & I & cerebral art. & 3.0 & alive \\
2 & M & 46 & I & coronary art. & 4.2 & alive \\
3 & F & 43 & I & cerebral art. & 4.4 & alive \\
4 & M & 49 & I & coronary art. & 5.2 & alive \\
5 & F & 44 & I & cerebral art. & 7.0 & alive \\
6 & M & 49 & I & cerebral art. & 7.8 & dead \\
7 & F & 51 & I & cerebral art. & 9.8 & alive \\
8 & M & 36 & II & cerebral art. & 10.9 & alive \\
9 & F & 54 & I & cerebral art. & 11.2 & dead \\
10 & F & 32 & I & cerebral art. & 12.2 & dead \\
\hline
\end{tabular}

F : female, $M$ : male, art. : artery 
Table 3 Causes of late death

\begin{tabular}{l|l|l}
\hline & \multicolumn{1}{|c|}{$\begin{array}{c}\text { Group I } \\
(\mathrm{n}=36)\end{array}$} & $\begin{array}{c}\text { Group II } \\
(\mathrm{n}=28)\end{array}$ \\
\hline No. of patients & $6(1.8 \% / \mathrm{py})$ & $2(0.9 \% / \mathrm{py})$ \\
\hline Thromboembolism & 3 & 0 \\
Acute heart failure & 1 & 0 \\
Re-operation & 0 & 1 \\
Suicide & 2 & 0 \\
Unknown & 0 & 1 \\
\hline
\end{tabular}

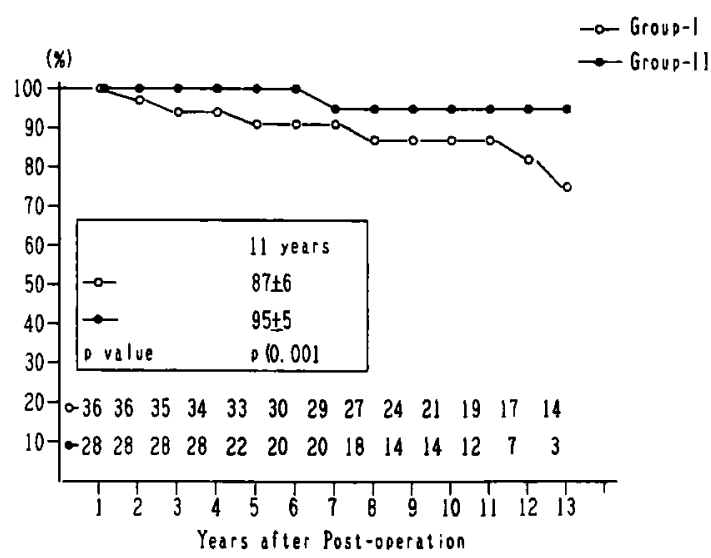

Fig. 2 Actuarial survival rates

py）で血栓塞栓症がその50\%を占めた。II群では 2 例 (0.9\%/py)で血栓塞栓症による死亡はなかった。累積 生存率では11年目で II 群の $95 \pm 5 \%$ に比へ, I 群では $87 \pm 6 \%$ と有意（p<0.00）に低値を示した（図 2$).$

II群の抗凝固療法の内容を表 4 に示す. 抗血小板剤 の服用例か $68 \%$ (19例) を占め, そのうちの68\%(13 例) が aspirin 単独服用例であった. 血栓塞栓症は wafarin 単独服用例の 1 例のみであった.

重回㷌分析による血栓塞栓症の発生とその危険因子 としてこれまで指摘されてきた NYHA 臨床度, 抗凝 固療法の有無, 心房細動の有無, 左房内血栓の有無, 術前血栓塞栓症の既往の有無と相関の順位づけは表 5 のとうりである. 有意相関を示したものは抗疑固療法 の有無と術前血栓塞栓症の既往の有無であった。 また $\mathrm{t}$ の絶対值から抗凝固療法の有無が最も高い相関を示 した.

抗凝固療法の有無により分類したI, II群間におけ るこれらの危険因子の割合を表 6 に示す. NYHA 臨 床度の割合は両群間に有意差はなく, 心房細動の合併 の割合はそれぞれ72\%，71\%，術前血栓塞栓症の合併
Table 4 Method of anticoagulation therapy

\begin{tabular}{l|c|c}
\hline & $\begin{array}{c}\text { No. of } \\
\text { patients }\end{array}$ & $\begin{array}{c}\text { Thromboembolism } \\
\text { event }\end{array}$ \\
\hline Antiplatelet & 19 & 0 \\
$\begin{array}{c}\text { aspirin (A) } \\
(81-330 \mathrm{mg} / \text { day) } \\
\text { dipyridamole (D) } \\
(300 \mathrm{mg} / \text { day) } \\
\text { ticlopidine (T) } \\
(300 \mathrm{mg} / \text { day) }\end{array}$ & 13 & \\
A+T & 1 & \\
\hline Warfarin (W) & 1 & \\
\hline W & 9 & 1 \\
W+D & 7 & 1 \\
W+A & 1 & \\
\hline
\end{tabular}

Table 5 Multivariate analysis for the thromboembolic risk factors

\begin{tabular}{l|c|c|c}
\hline Risk factor & $\begin{array}{c}\text { Regression } \\
\text { coefficient }\end{array}$ & $t$ value & P value \\
\hline NYHA & 0.077 & 0.8607 & NS \\
Anticoa. & -0.258 & -2.8704 & $\mathrm{p}<0.01$ \\
Af & 0.140 & 1.4042 & NS \\
LAT & -0.070 & -0.4247 & NS \\
Preop-th. & 0.355 & 2.6970 & $\mathrm{p}<0.01$ \\
\hline
\end{tabular}

NYHA : functional class of New York Heart Association Anticoa. : anticoagulation therapy

Af : atrial fibrillation

LAT : left atrial thrombus

Preop-th. : episode of preoperative thromboembolism

Table 6 Comparison of patients with thromboembolic risk factors between Group I without anticoagulation and Group II with anticoagulation

\begin{tabular}{lc|c|c|c}
\hline & & \multicolumn{1}{|c|}{ Group I } & Group II & P value \\
\hline NYHA FC II & $15 / 36(42 \%)$ & $10 / 28(36 \%)$ & NS \\
& III & $20 / 36(56 \%)$ & $17 / 28(61 \%)$ & NS \\
\hline IV & $1 / 36(3 \%)$ & $1 / 28(4 \%)$ & NS \\
\hline LAT & $26 / 36(72 \%)$ & $20 / 28(71 \%)$ & NS \\
\hline Preop-th. & $1 / 36(3 \%)$ & $5 / 28(18 \%)$ & p<0.05 \\
\hline
\end{tabular}

NYHA FC : functional class of New York Heart Associa. tion

Af : atrial fibrillation

LAT : left atrial thrombus

Preop-th. : episode of preoperative thromboembolism 
の割合は11\%，18\%と有意差はなかった．左房内血栓 の合併の割合は I 群の $3 \%$ \%比べII群で $18 \%$ と有意に 高かった $(p<0.05)$.

\section{考察}

僧帽弁狭窄症における血栓塞栓症の発生頻度 1.2 1.8\%/患者・年 ${ }^{36)}$ は人工弁による僧帽弁置換術

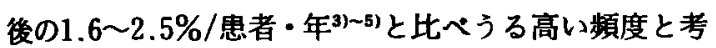
えられる。これまでに血栓塞栓症の危険因子について は多くの研究が行われてきた. 抗凝固療法, 心房細動, 左房内血栓, 術前血栓塞栓症の既往の有無やNYHA 臨床度などが血拴塞栓症の合併と有意な相関をも つヤー11とされてきた，今回の検討では，そのうち抗凝 固療法の有無が血栓塞栓症の危険因子として最も高い 相関を示した。にもかかわらず OMC 後における抗凝 固療法が人工弁置換術後ほど厳密に行われていないの は, 血拴弁のような重篤な合併症が少ないこと, 抗凝 固療法、ことに warfarinを服用した場合には， $1.2 \sim 3.8 \% / \mathrm{py}^{(3) 1213)}$ と高頻度に重篤な出血性合併症 がみられること, quality of life の重視などが主な理由 と思われる。

今回の研究結果は, 抗血小板剂あるいは warfarin, またはその両者の併用などなんらかの抗凝固療法を行 えは，行わない場合に比へて OMC 後の血栓塞栓症の 合併が有意に少なく，それが長期生存率の有意差に大 きな影響を及はすすことを示し，全ての OMC 後の症例 に何らかの抗凝固療法を行うべきであることを示唆す るものと思われる。

どのような抗凝固療法が OMC 後には望まれるのか は，難しい問題である. 敩密な warfarin によるコント ロールを行えぼ, 重篤な出血性合併症や quality of life が問題となろう．抗血小板刻単独では充分な抗凝固療 法という観点から不安が残る。しかし今回の研究結果 は, 出血性合併症の危険の少ない抗血小板剂の服用が OMC 後の血栓塞栓症の予防と生存率の改善に有用で あることを示した。

\section{結語}

$\mathrm{OMC}$ 後の抗凝固療法について, 行わなかった群, 行った群における血栓塞拴症危険因子, 血拴塞栓症 event free rate, 迋隔期死亡原因, 累積生存率の比率 からその有用性に関して検討した。

$\mathrm{OMC}$ 後の抗凝固療法, ことに抗血小板剤は血栓塞 拴症の予防と累積生存率の改善に有用であった。

\section{文献}

1) 鈴木伸一, 近藤治郎, 井元清隆他：閉鎖式僧帽弁交
連開術の長期遠隔成績一直視下交連切開術び弁置 換術との比較検討. 日胸外会誌 $41: 1460-1466$, 1993

2) Eguaras MG, Luque I, Montero A, et al: A comparison of repair and replacement for mitral stenosis with partially calcified valve. J Thorac Cardiovasc Surg 100:161-166, 1990

3）戸田省吾, 大賀興一, 丹生智史他：僧帽弁手術症例 における術後血栓塞拴症一弁置換術と交連切開術 との比較一. 日胸外会誌 $37: 1359-1364,1989$

4) Lindblom D: Long-term clinical results after mitral valve replacement with Bjork-Shiley prosthesis. J Thorac Cardiovasc Surg 95 : 321333. 1988

5) Arom KV, Nicoloff DM, Kersten TE, et al: Ten years' experience with the St. Jude Medical valve prosthesis. Ann Thorac Surg 47: 831 $-837,1989$

6) Cohn LH, Allred EN, Cohn LA, et al: Longterm results of opem mitral valve reconstruction for mitral stenosis. Am J Cardiol 55 : 731734,1985

7) Ellis LB, Harken DE: Arterial embolization in relation to mitral valvuloplasty. Am Heart J 62: 611-620, 1961

8) Eberlein U, Von der Emde J, Rein J, et al: Thromboembolic and bleeding complications after mitral valve replacement. Eur J Cardiothorac Surg $4: 605-612,1990$

9) Davison G, Greenland P: Predictors of left atrial thrombus in mitral valve disease. J Gen Intern Med 6 : 108-112, 1991

10) John S, Bashi VV, Ravikumar E, et al: Closed mitral valvotomy in the older subject. Results in 367 consecutive patients. J Cardiovasc Surg $31: 14-19,1990$

11) Gautam PC, Coulshed N, Epstein EJ, et al: Preoperative clinical predictors of long term survival in mitral stenosis: Analysis of 200 cases followed for up to 27 years after closed mitral valvotomy. Thorax 41:401-406, 1986

12) Anderson RP, Boncheck LI, Grunkemeier GL, et al: The analysis and presentation of surgical results by actuarial methods. J Surg Res 16 : 224-230, 1974

13) Czer LSC, Chaux A, Matloff JM, et al: Ten- 
year experience with the St. Jude Medical valve for primary valve replacement. J Thorac Cardiovasc Surg 100:44-55, 1990

14) Altman R, Rouvier J, Gurfinkel E, et al : Com- parison of two levels of anticoagulation therapy in patients with substitute heart valves. $J$ Thorac Cardiovasc Surg 101: 427-431, 1991

\title{
A STUDY ON THE USEFULNESS OF ANTICOAGULATION THERAPY IN MITRAL STENOSIS AFTER OPEN MITRAL COMMISSUROTOMY
}

\author{
Kenji OKAMURA, Naotaka ATSUMI, Tomoaki JIKUYA, Yuzuru SAKAKIBARA \\ and Toshio MITSUI \\ Department of Cardiovascular Surgery, Institute of Clinical Medicine, University of Tsukuba
}

Thromboembolism is one of the most serious complications, which affects the patient's morbidity and mortality, after open mitral commissurotomy (OMC) in mitral stenosis. This report aims to clarify whether the anticoagulation therapy could decrease this serious complication or not, by comparing the thromboembolism event free rate, causes of late deaths and cumulative survival rate between 36 patients without (group I) and 28 patients with (group II) anticoagulation therapy. Simultaneously, the risk factors of thromboembolism, that is, with or without anticoagulation therapy, atrial fibrillation, left atrial thrombus, preoperatively complicated thromboembolism and functional class of NYHA, have been ranked by multivariate analysis. Oral antiplatelet drugs in $68 \%$ and warfarin in $32 \%$ of group II patients were used for the anticoagulation therapy.

A linearized rate of thromboembolism in group I was $2.7 \% / \mathrm{py}$ and significantly higher than that of group II in $0.4 \%$.py. The actuarial freedom from thromboembolism in group I was $77 \pm 10 \%$ and significantly lower than that of group II in $90 \pm 9 \%$ at 11 years after the operation. The cumulative survival rate at 11 years showed significantly good result of $95 \pm 5 \%$ in group II comparing with the result of $87 \pm 6 \%$ in group I. The multivariate analysis showed the msot significant inter-relationship between the anticoagulation therapy and thromboembolism as a risk factor. Thus, the anticoagulation therapy, especially antiplatelet therapy, after $\mathrm{OMC}$, was useful for the prevention of thromboembolism and the improvement of the cumulative survival rate. 